\title{
The creditworthiness of individuals as a risk factor for the socio-economic security of the region
}

\author{
Elena Karanina $^{1, *}$, Ekaterina Selezneva ${ }^{1}$, and Svetlana Chuchkalova $^{1}$ \\ ${ }^{1}$ Vyatka State University, Moskovskaya St., 36, 610000 Kirov, Russia
}

\begin{abstract}
The growth of the debt burden of the population of the regions of Russia due to the growth of unsecured consumer loans is contrary to plans to ensure economic development. It is necessary to eliminate the threat of excessive lending as a risk factor for the security of households and the economy as a whole. The purpose of the study is to analyze the state of lending and the level of creditworthiness of the population as a risk factor for the socio-economic security of the region and develop initiatives to reduce the negative impact of this factor on the economy of the region. The following research methods are used: bibliographic method, statistical and economic-mathematical research methods. During the study, the following results were achieved: a) an analysis of the volumes and risks of lending to individuals is presented; b) the analysis of the creditworthiness of the population in the regions is presented (on the example of the Volga Federal District); c) initiatives were proposed to reduce the impact of debt on the living standards of the population and the economy of the regions of the Volga Federal District.
\end{abstract}

\section{Introduction}

In modern Russian economic conditions, the primary task is to create a unified mechanism for managing the regional economy, which would help to finally overcome the negative phenomena. In addition, it is necessary to create conditions for social and economic security, both in the field of Finance and in the field of intensification of production, agriculture and other industries. An important role for economic development is played by the development credit facility as part of the credit system, as it is one of the main instruments of infusion of additional funds for consumer activity, which starts the process of development of almost all sectors of the economy of the region and the country as a whole. Proper organization of the credit mechanism will help ensure effective redistribution of funds between sectors of the economy. But at the same time, incorrect, thoughtless, highrisk lending to the population leads to a decrease in economic activity in the consumer market and in the economy as a whole. Over-crediting of the population does not allow to realize the needs of the population in the market, reduces the quality of life of the

* Corresponding author: kafinanc@yandex.ru 
population, leads to an unfavorable social situation in the region. These processes are compounded by the uncontrolled activity of microfinance organizations, collection agencies and departments for problem loans of banks.

\section{Analysis of lending to individuals in the Russian Federation and regions of the Volga Federal district}

The total loan portfolio of Russian banks increased by $15 \%$ in 2018 to 52.9 trillion rubles. This has largely determined the overall dynamics of the sector. The volume of the loan portfolio as of January 1.2019 exceeds $57 \%$ of assets. The dynamics of the loan portfolio in all four quarters was positive, the most noticeable growth was observed in the third quarter $-5.3 \%$ [9].

The share of foreign currency loans continues to decline. In the corporate portfolio, their share for 2018 decreased from $29.7 \%$ to $28.8 \%$ (at the beginning of $2017-32.2 \%$ ), in the retail portfolio - from $0.9 \%$ to $0.7 \%$ (at the beginning of $2017-1.5 \%$ ). By January 1,2019 , the balance sheets of the five largest banks held $67.4 \%$ of the total amount of loans issued, while the top 100 loan portfolios accounted for $97.3 \%$ (63.4\% and $96.9 \%$, respectively, a year earlier) (table 1).

Table 1. Structure of turnover on loans granted by credit organizations to individuals in rubles, by urgency.

\begin{tabular}{|c|c|c|c|c|c|c|c|c|}
\hline & \multicolumn{10}{|c|}{ Period } & $\begin{array}{c}\text { up to } 30 \\
\text { days, } \\
\text { including } \\
\text { «on } \\
\text { demand» }\end{array}$ & $\begin{array}{c}\text { from } \\
31 \text { to } \\
90 \\
\text { days }\end{array}$ & $\begin{array}{c}\text { from } \\
91 \text { to } \\
180 \\
\text { days }\end{array}$ & $\begin{array}{c}\text { from } \\
181 \\
\text { days } \\
\text { to 1 } \\
\text { year }\end{array}$ & $\begin{array}{c}\text { up to 1 year, } \\
\text { including } \\
\text { «on } \\
\text { demand» }\end{array}$ & $\begin{array}{c}\text { from } \\
1 \text { year } \\
\text { to 3 } \\
\text { years }\end{array}$ & $\begin{array}{c}\text { over 3 } \\
\text { years }\end{array}$ & $\begin{array}{c}\text { over } \\
\text { year }\end{array}$ \\
\hline $\begin{array}{c}\text { January } \\
2014\end{array}$ & 1.56 & 0.75 & 1.00 & 8.98 & 12.29 & 20.32 & 67.39 & 87.71 \\
\hline $\begin{array}{c}\text { January } \\
2015\end{array}$ & 3.38 & 1.32 & 2.40 & 7.89 & 14.99 & 14.49 & 70.51 & 85.01 \\
\hline $\begin{array}{c}\text { January } \\
2016\end{array}$ & 0.24 & 0.50 & 0.78 & 7.86 & 9.38 & 21.93 & 68.69 & 90.62 \\
\hline $\begin{array}{c}\text { January } \\
2017\end{array}$ & 0.18 & 0.48 & 0.47 & 7.29 & 8.42 & 23.92 & 67.66 & 91.58 \\
\hline $\begin{array}{c}\text { January } \\
2018\end{array}$ & 0.05 & 0.24 & 0.24 & 4.42 & 4.95 & 17.21 & 77.84 & 95.05 \\
\hline $\begin{array}{c}\text { January } \\
2019\end{array}$ & 0.04 & 0.13 & 0.18 & 3.92 & 4.27 & 15.38 & 80.35 & 95.73 \\
\hline
\end{tabular}

The share of retail loans in the total credit portfolio of the Russian banking sector increased from $25.3 \%$ to $26.8 \%$ over the year, and the share of other loans increased [10]. At the same time, the share of corporate loans, respectively, decreased from $70.2 \%$ to $68.3 \%$. The banking sector's loan portfolio increased by $10.7 \% 1$ due to an increase in loans to non-financial organizations and individuals by $5.8 \% 1$ and $22.8 \% 1$, respectively (adjusted for currency revaluation) (figure 1). 


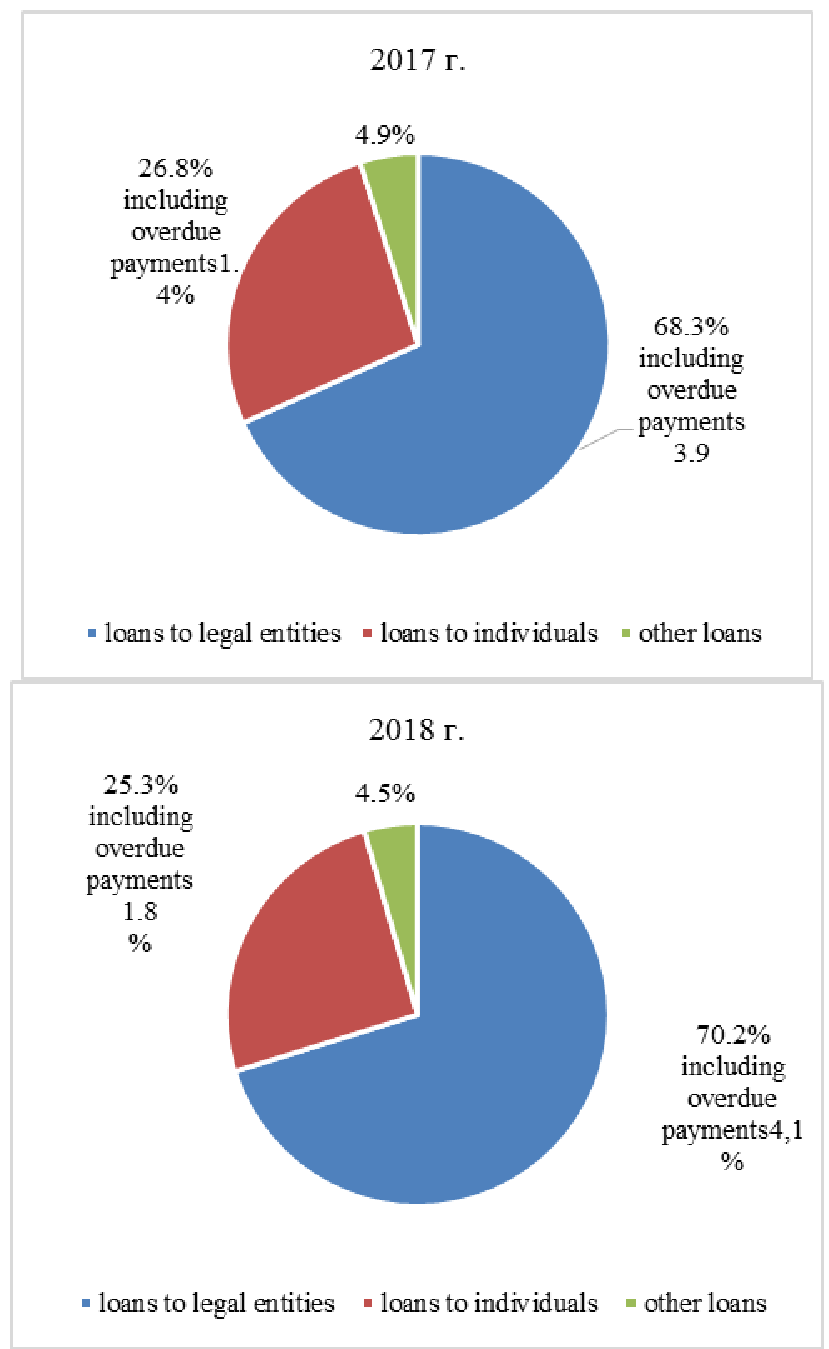

Fig. 1. Structure of lending by the Russian banking sector, \%.

The sphere of lending to the population in the regions of the Volga Federal district and the Russian Federation as a whole changed during the study period due to various factors. The economy has adapted to the international sectoral sanctions imposed against the Russian Federation. The situation on the labor market has improved. The unemployment rate fell to $4.8 \% 1$ by the end of 2018 , compared to $5.1 \% 1$ in December last year. Real accrued wages increased by $6.8 \% 1$ year-on-year against a $2.9 \% 1$ increase in 2017 . The growth of wages in the economy was supported by an increase in the wages of state employees under the decrees of the President of the Russian Federation and an increase in the minimum wage. Real disposable income of the population (taking into account the onetime cash payment to pensioners in January 2017) decreased by $0.2 \%$ in annual terms against a fall of $1.2 \% 1$ in 2017 . The income of the population was supported by the growth of wages and the indexation of pensions. Retail trade turnover in 2018 increased by $2.6 \%$; in 2017 , the growth rate was $1.3 \%$ [16]. The population's propensity to accumulate savings has decreased. The share of cash income spent on savings decreased from $8.1 \% 1$ in 2017 to $5.6 \% 1$ in 2018. The consumer confidence index, which reflects the total consumer expectations of the population, decreased by 6 percentage points in the fourth quarter of 
2018 compared to the fourth quarter of 2017 and amounted to minus 17\%. Annual inflation accelerated to $4.3 \% 1$ by the end of 2018 , compared to $2.5 \% 1$ in December 2017 . The acceleration is due to preparations for an increase in VAT from $18 \%$ to $20 \%$, the weakening of the Russian ruble against the background of capital outflows and growing geopolitical tensions, as well as a weak harvest. This led to the Bank of Russia tightening its monetary policy in the second half of the year. The key rate decreased during 2018, and by the end of 2018 it returned to its initial value in relation to 2017 and remained at the level of $7.75 \%$ (table 2).

Table 2. Weighted average interest rates on loans granted by credit institutions to individuals in rubles.

\begin{tabular}{|c|c|c|c|c|c|c|c|c|}
\hline \multirow{2}{*}{ Period } & \multicolumn{10}{|c|}{$\begin{array}{c}\text { Tp to 30 } \\
\text { days, } \\
\text { including } \\
\text { «on } \\
\text { demand» }\end{array}$} & $\begin{array}{c}\text { from } \\
31 \text { to } \\
90 \\
\text { days }\end{array}$ & $\begin{array}{c}\text { from } \\
91 \text { to } \\
180 \\
\text { days }\end{array}$ & $\begin{array}{c}\text { from } \\
181 \\
\text { days to } \\
1 \text { year }\end{array}$ & $\begin{array}{c}\text { up to 1 } \\
\text { year, } \\
\text { including } \\
\text { «on } \\
\text { demand» }\end{array}$ & $\begin{array}{c}\text { from 1 year to } \\
3 \text { years }\end{array}$ & $\begin{array}{c}\text { over 3 } \\
\text { years }\end{array}$ & $\begin{array}{c}\text { over } \\
1 \\
\text { year }\end{array}$ \\
\hline $\begin{array}{c}\text { January } \\
2014\end{array}$ & 28.04 & 16.09 & 30.39 & 23.81 & 24.41 & 21.69 & 17.29 & 18.31 \\
\hline $\begin{array}{c}\text { January } \\
2015\end{array}$ & 23.69 & 19.94 & 27.00 & 33.55 & 29.08 & 29.69 & 17.36 & 19.46 \\
\hline $\begin{array}{c}\text { January } \\
2016\end{array}$ & 17.74 & 20.24 & 22.37 & 26.30 & 25.43 & 21.30 & 17.09 & 18.11 \\
\hline $\begin{array}{c}\text { January } \\
2017\end{array}$ & 18.26 & 18.17 & 22.81 & 22.76 & 22.40 & 18.08 & 15.58 & 16.23 \\
\hline $\begin{array}{c}\text { January } \\
2018\end{array}$ & 17.30 & 16.62 & 21.13 & 19.01 & 18.99 & 15.91 & 12.99 & 13.52 \\
\hline $\begin{array}{c}\text { January } \\
2019\end{array}$ & 12.75 & 16.68 & 18.84 & 15.82 & 15.95 & 15.08 & 12.73 & 13.10 \\
\hline
\end{tabular}

In 2018 , the average interest rate for loans under 1 year was $21.26 \%$, and for loans with a term of more than 1 year- $16.95 \%[13]$.

With its latest amendments to mandatory Bank regulations, the Central Bank of the Russian Federation increased the risk ratio on loans to $300 \%$. This percentage is applicable to loans issued from April 1, 2015. The purpose of this protective measure is to prevent the accumulation of excessive risks in the foreign exchange lending segment. This will help to insure financial institutions against possible non-payment of loans by consumers.

For the creditors themselves, doubling the risk ratio is very unprofitable. This may lead to the fact that credit institutions will be forced to either significantly raise rates, or even abandon foreign exchange loan programs.

Interest rates on loans are also formed under the influence of many other factors - the cost of resources attracted by a credit institution for lending purposes, the level and rate of inflation, the state of the national credit market, and so on. the Determining elements of the cost of credit are the costs of the credit organization to raise funds and its operating expenses. On the other hand, the higher the interest income of credit institutions on loans granted to the population, the higher the efficiency of their activities. However, in this case, it is necessary to assume that there is a limit of purchasing power, when exceeding which the demand for retail loans begins to decrease, respectively, the relationship between the efficiency of banking activities and loan rates may be reversed. It follows that the improvement of interest rates on retail loans can not be considered only from the perspective of the borrower, i.e. their reduction, or only from the position of the credit institution, i.e. their increase. Therefore, banks in their lending activities must find the optimal amount of interest rates that take into account the interests of all participants in 
credit relations, i.e., able to reduce the credit burden of borrowers while achieving the effectiveness of the Bank's lending operations[12].

Lending to individuals, due to which, in many ways, there was a good dynamics of growth in the loan portfolio in 2018, obviously, will not show such an impressive growth in 2020: both the growth of interest rates and the restrictions of the regulator regarding unsecured loans and mortgages with or without a low down payment will affect. This will affect the dynamics of retail lending and the lack of income growth. This same factor will contribute to the deterioration of the quality of credit portfolios of Russian banks in 2019 . Mortgage lending will continue to support the growth of retail lending.

The most active borrowers are people aged 25-44 years. The average debtor lives in the Siberian or Ural Federal district. He is a resident of a large city, with a population of 250 to 1 million people. He has a higher or secondary technical education and an income of 30 thousand rubles.

According to banks, $13 \%$ of borrowers take money from them in order to pay off old debts. About $7 \%$ of Russians spend money received from credit and financial institutions for treatment, $5 \%$ for weddings, funerals and vacations, and $1 \%$ for training. Currently, $59 \%$ of the working-age population of the country has loans [14].

Conducted surveys of the country's population gave the following results:

1.Every third Russian has a loan. Of these, $63 \%$ pay loans for consumer needs and $37 \%$ mortgages.

2. Mortgage lending is popular among people who have an income «below average».

3. Consumer loans are used by people with very low income. They often buy household appliances with the loan amount.

4. Every fourth Russian buys a car on credit.

A negative factor in the development of the credit sector is the level of creditworthiness of the population.

\section{Analysis of the creditworthiness of individuals in the Russian Federation and the regions of the Volga Federal district}

The population's debt burden in 2018 increased from 2 to 4 times in relation to 2010. the Problem of high debt burden in the regions was repeatedly raised by Russian President Vladimir Putin [12]. The increase in the population's debt burden due to unsecured consumer loans goes against the need to reduce rates for the sake of mortgage growth, which is declared a priority within national projects. Although the population's debt burden is still lower than in other countries, the tendency to increase this indicator causes concerns of the Central Bank, since it is not sensitive to the measures taken by the regulator [16].

Debt on loans in rubles provided by credit organizations to individuals per capita is shown in figure 2.

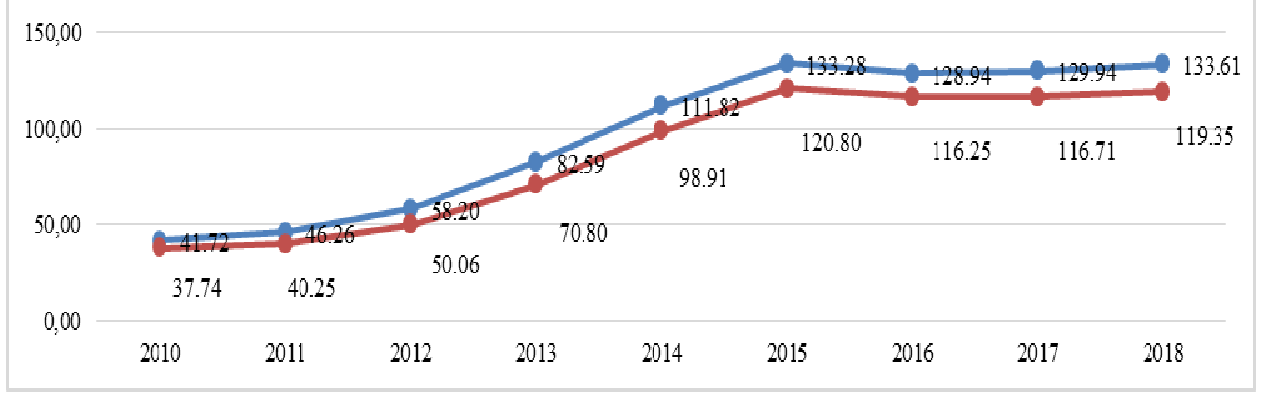

Fig. 2. Debt on loans of individuals per capita, thousand rubles. 
This indicator decreased slightly on average in the Russian Federation, but the increase is observed in the Mordovia, Chuvashia, Kirov, Penza, Samara, and Ulyanovsk regions. In some areas, overdue debt reaches $20-25 \%$ of per capita income. Thus, when adding up current and overdue debt, the debt burden reaches up to $80 \%$ or more, that is, only $20 \%$ of the population's income remains to meet the needs, this is a colossally low figure, and so with relatively low incomes of the population. According to the Central Bank, $13 \%$ of borrowers take money from banks in order to pay off old debts (figure 3 ).

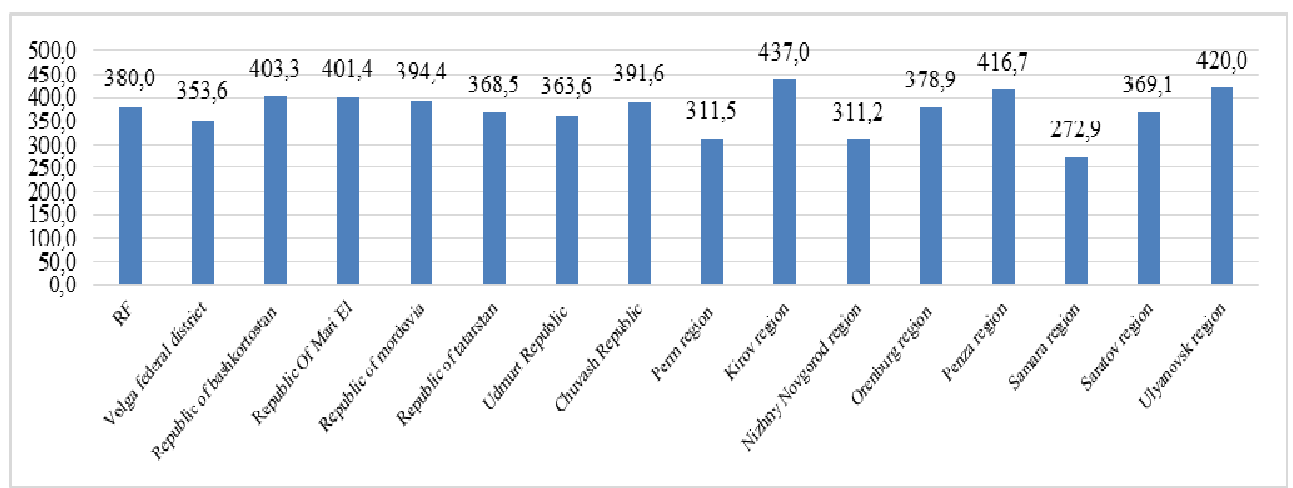

Fig. 3. Change in debt for the period, $\%$.

About 7\% of Russians spend money received from credit and financial institutions for treatment, $5 \%$ for weddings, funerals and vacations, $1 \%$ for training, and the rest take on consumer loans. Currently, 59\% of the working-age population of the country has loans and further growth is observed[12].

If we compare Russians with Europeans, the picture of their debts does not look as disastrous as for residents of the EU and the United States [15]. Currently, the latter owe banks $98 \%$ of their annual income. The debts of Russians are still only $25 \%$ of the income they received for the year (figure 4).

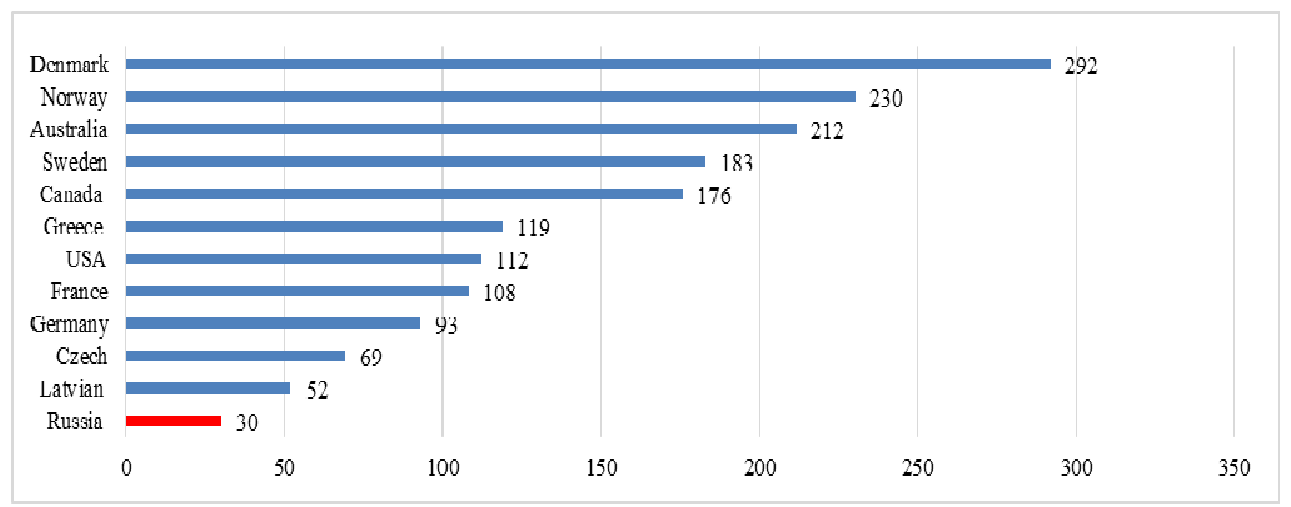

Fig. 4. Family debt burden as a percentage of disposable income.

It is important to understand that interest rates on loans issued in Russia are significantly higher than in Europe. Despite the high level of debt, banks do not stop the flow of loans. They will continue to do this until lending becomes a loss-making business for them. In 2018, their return averaged 10.4\%. According to experts, credit and financial organizations earned more than 1.9 trillion in a year. Rubles [16].

The growth of retail lending is shown in figure 5. 


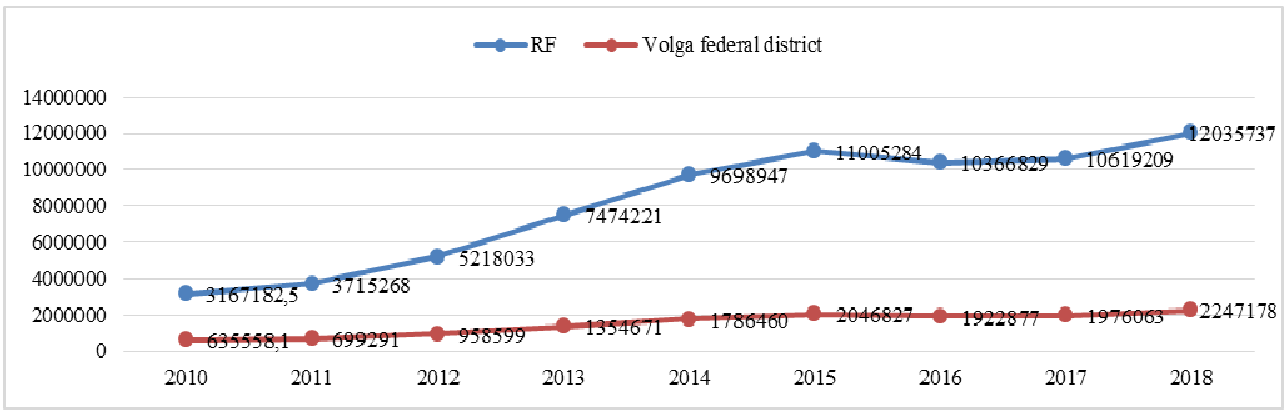

Fig. 5. Dynamics of retail lending, mln. RUB.

Despite the measures taken by the Central Bank, the growth of retail lending in Russia as a whole in 2018 reached almost $300 \%$ in 5 years, and the ratio of consumer loans per capita to monthly wages reached $133 \%$, closely approaching the level of 2015 . The largest increase in loans, more than 3 times, was recorded in Bashkortostan, Mari El, Tatarstan, Kirov, Orenburg, Saratov, and Ulyanovsk regions.

In September 2018, the Central Bank increased the risk factors for unsecured loans with a rate from 10 to $30 \%$. The increase in risk ratios suggests that banks need more capital to secure loans than before, which makes increasing lending less profitable. But these measures gave very low efficiency and the level of credit security did not increase[14].

The regulator needs to apply more drastic measures -the limit on the debt load, that is, if the borrower uses a significant part (50\%) of its income to pay off existing loans, then it is no longer possible to take an additional loan[13].

Analysts estimated that in 2018, the average Russian family's debt was 234 thousand rubles. Its growth is $19 \%$. The share of» bad « debts reached $5.2 \%$. The problem is related to the fact that people have a lot of debt and they are gaining additional due to the fact that banks refinance existing debt, crediting them, extending the terms. The growth of overdue debt is also a significant problem. data on this indicator for 2010-2018 are presented in figure 6 .

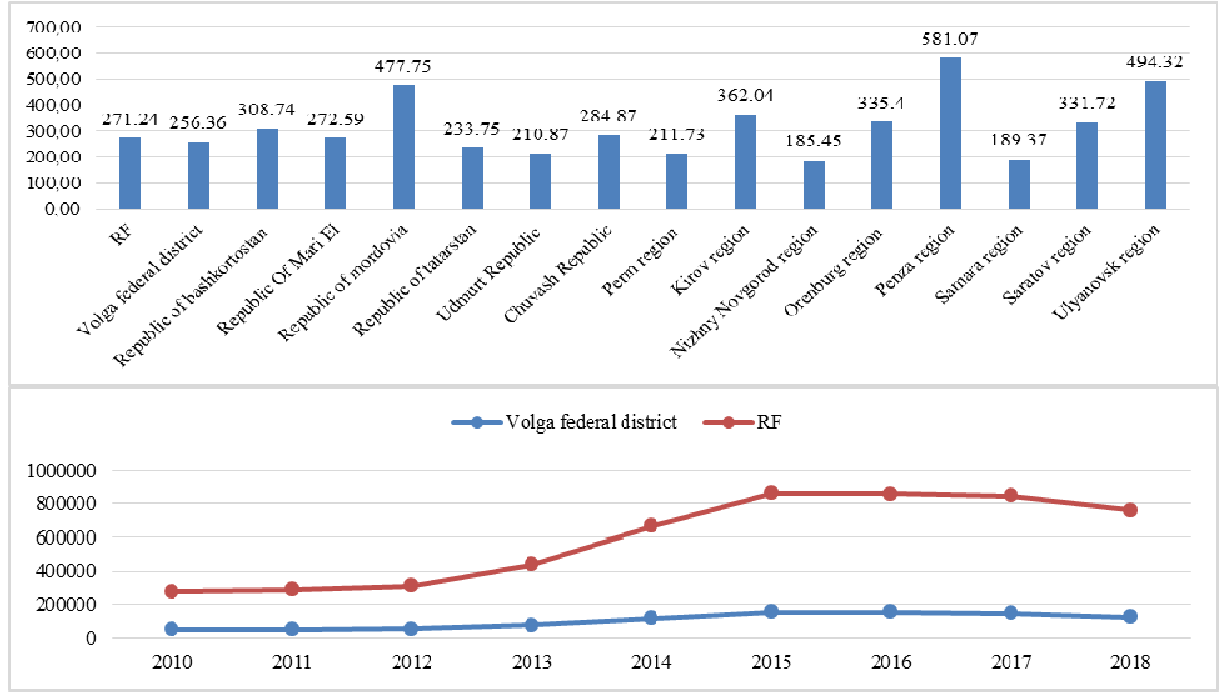

Fig. 6. Change in overdue debt for the period $2010-2018, \%$. 
The largest increase in overdue debt was recorded in the Republic of Mordovia, Chuvashia, Penza and Orenburg regions. All this becomes a problem for the population, as with the growth of overdue debt, the amount of fines, penalties and penalties also increases. Every year, the level of debt in the average annual salary also increases [9].

It is important to correlate the debts of individuals to banks on average per employee in table 3 .

Table 3. The amount of debt owed by individuals to banks on average per employee, thousand rubles.

\begin{tabular}{|c|c|c|c|c|c|c|c|c|c|}
\hline Regions & 2010 & 2011 & 2012 & 4,14 & 2014 & 2015 & 2016 & 2017 & 2018 \\
\hline $\mathrm{RF}$ & 46.93 & 54.92 & 76.77 & 110.08 & 143.02 & 151.95 & 143.85 & 147.81 & 167.53 \\
\hline $\begin{array}{l}\text { Volga } \\
\text { federal } \\
\text { district }\end{array}$ & 44.48 & 48.92 & 66.86 & 95.29 & 126.57 & 143.93 & 136.22 & 142.63 & 162.19 \\
\hline $\begin{array}{c}\text { Republic of } \\
\text { bashkortost } \\
\text { an }\end{array}$ & 45.33 & 50.75 & 69.32 & 103.53 & 144.84 & 163.51 & 154.19 & 161.69 & 187.09 \\
\hline $\begin{array}{c}\text { Republic of } \\
\text { Mari El }\end{array}$ & 34.75 & 38.49 & 51.72 & 74.56 & 99.61 & 121.78 & 118.93 & 133.42 & 152.10 \\
\hline $\begin{array}{c}\text { Republic of } \\
\text { mordovia }\end{array}$ & 33.11 & 36.24 & 49.20 & 70.91 & 94.91 & 105.00 & 103.11 & 111.19 & 129.87 \\
\hline $\begin{array}{c}\text { Republic of } \\
\text { tatarstan }\end{array}$ & 46.39 & 49.64 & 70.99 & 102.44 & 135.64 & 142.71 & 132.83 & 138.90 & 159.12 \\
\hline $\begin{array}{l}\text { Udmurt } \\
\text { Republic }\end{array}$ & 46.90 & 49.60 & 66.24 & 93.21 & 129.92 & 150.76 & 148.73 & 159.51 & 180.58 \\
\hline $\begin{array}{l}\text { Chuvash } \\
\text { Republic }\end{array}$ & 41.68 & 44.52 & 59.35 & 85.06 & 115.88 & 137.46 & 140.15 & 153.54 & 177.25 \\
\hline $\begin{array}{l}\text { Perm } \\
\text { region }\end{array}$ & 57.50 & 60.57 & 84.58 & 121.62 & 155.50 & 183.49 & 171.63 & 178.34 & 199.24 \\
\hline $\begin{array}{l}\text { Kirov } \\
\text { region }\end{array}$ & 31.90 & 36.08 & 51.15 & 77.22 & 107.44 & 131.22 & 129.17 & 134.69 & 155.55 \\
\hline $\begin{array}{c}\text { Nizhny } \\
\text { Novgorod } \\
\text { region } \\
\end{array}$ & 44.28 & 48.84 & 63.80 & 85.74 & 112.04 & 130.64 & 123.16 & 124.92 & 142.15 \\
\hline $\begin{array}{l}\text { Orenburg } \\
\text { region }\end{array}$ & 41.06 & 46.36 & 62.97 & 88.77 & 122.34 & 160.27 & 151.30 & 154.58 & 172.81 \\
\hline $\begin{array}{l}\text { Penza } \\
\text { region }\end{array}$ & 29.69 & 34.04 & 47.99 & 69.32 & 95.00 & 117.22 & 113.02 & 120.50 & 136.09 \\
\hline $\begin{array}{c}\text { Samara } \\
\text { region }\end{array}$ & 60.57 & 64.51 & 84.62 & 114.31 & 135.26 & 133.20 & 126.62 & 133.06 & 150.55 \\
\hline $\begin{array}{l}\text { Saratov } \\
\text { region }\end{array}$ & 34.46 & 39.01 & 54.42 & 79.27 & 108.42 & 126.88 & 119.46 & 125.89 & 142.11 \\
\hline $\begin{array}{l}\text { Ulyanovsk } \\
\text { region }\end{array}$ & 36.57 & 48.61 & 69.39 & 101.58 & 140.82 & 161.57 & 137.70 & 142.80 & 159.35 \\
\hline
\end{tabular}

The total amount of debt obligations of citizens significantly exceeds their savings. The difference is about $700 \%$. At the end of 2018 , the world Bank prepared a report on the state 
of the Russian economy, part of which was devoted to loans to citizens of the country. It noted that foreign currency loans are being withdrawn from the lending structure. Currently, they make up only $0.7 \%$ of the total amount of loans issued to the population [16].

The dynamics of the volume of debt owed by individuals to banks on average per employee in \% is shown in figure 7.

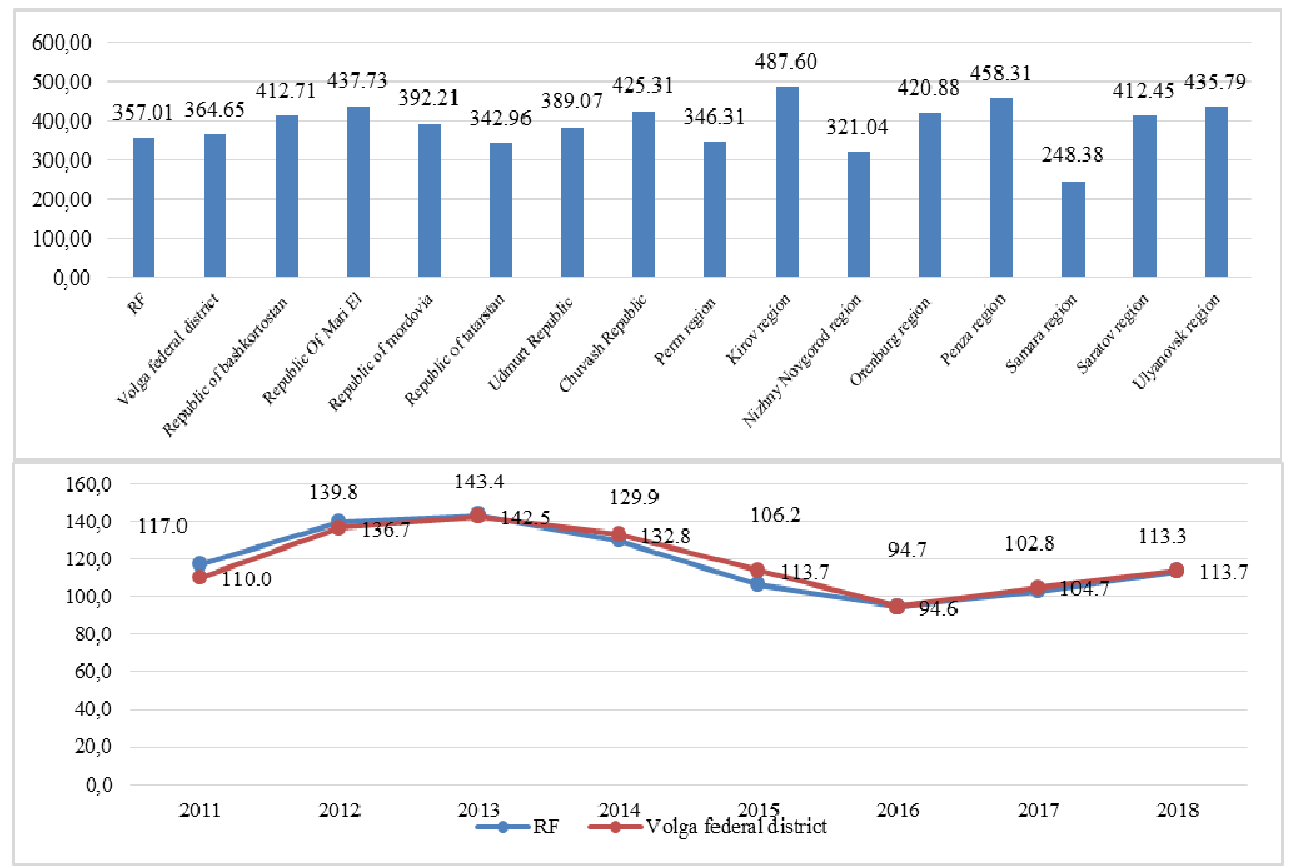

Fig. 7. Dynamics of the volume of debt owed by individuals to banks on average per employee from 2010-2018, thousand rubles.

According to official statistics of the Bank of Russia, the share of problem and bad loans in the total volume of the banking sector increased only slightly in 2018 - from $10 \%$ to $10.1 \%$. At the same time, despite the work of the regulator with banks in terms of adequate loan provisioning, the volume of formed reserves for all types of loans for 12 months decreased from $9.3 \%$ to $9.1 \%$ (at the beginning of 2017 , this figure was $8.5 \%$ ). This share is still less than the share of problem and bad loans alone in the total volume of loans [10].

An increase in the credit burden on the population with a constantly decreasing level of their income creates conditions for Russians to fall into long-term debt slavery. The decision taken by the Central Bank to increase the reserve rate forces credit and financial institutions to tighten the requirements imposed on borrowers. All this can cause a crisis in the country's banking sector. Experts believe that only 400 banks will remain in Russia in 2019 [10].

Falling incomes can lead to an increase in overdue debt and an increase in personal bankruptcies. More and more people in the country see this process as the only way out of debt slavery.

The table shows the risks of credit growth, a moderate risk is considered to be the ratio of debt on Bank loans to individuals and the average annual salary from 30 to $40 \%$, above $40 \%$ - a high risk (table 4 ). 
Table 4. Risk of the ratio of debt on Bank loans to individuals and the average annual salary, $\%$.

\begin{tabular}{|c|c|c|c|c|c|c|c|c|c|}
\hline Regions & 2010 & 2011 & 2012 & 2013 & 2014 & 2015 & 2016 & 2017 & 2018 \\
\hline RF & 18.66 & 19.59 & 24.03 & 30.79 & 36.68 & 37.21 & 32.66 & 31.45 & 32.13 \\
\hline $\begin{array}{l}\text { Volga federal } \\
\text { district }\end{array}$ & 23.74 & 23.24 & 27.83 & 35.32 & 42.87 & 46.79 & 41.63 & 40.72 & 42.44 \\
\hline $\begin{array}{c}\text { Republic of } \\
\text { bashkortostan }\end{array}$ & 23.07 & 22.99 & 28.50 & 38.56 & 48.30 & 52.55 & 45.71 & 44.38 & 47.22 \\
\hline $\begin{array}{c}\text { Republic Of } \\
\text { Mari El }\end{array}$ & 22.89 & 22.91 & 26.90 & 33.84 & 40.55 & 46.24 & 42.53 & 43.70 & 45.76 \\
\hline $\begin{array}{c}\text { Republic of } \\
\text { mordovia }\end{array}$ & 23.22 & 22.70 & 27.00 & 32.64 & 38.88 & 39.72 & 36.99 & 38.09 & 40.50 \\
\hline $\begin{array}{c}\text { Republic of } \\
\text { tatarstan }\end{array}$ & 22.28 & 20.67 & 25.46 & 32.79 & 39.95 & 40.80 & 36.62 & 35.81 & 37.72 \\
\hline $\begin{array}{c}\text { Udmurt } \\
\text { Republic }\end{array}$ & 27.35 & 26.09 & 30.26 & 36.90 & 46.23 & 50.88 & 46.43 & 45.84 & 47.33 \\
\hline $\begin{array}{l}\text { Chuvash } \\
\text { Republic }\end{array}$ & 26.71 & 24.91 & 28.78 & 36.56 & 46.30 & 53.60 & 50.98 & 52.16 & 54.67 \\
\hline Perm region & 27.48 & 26.89 & 32.30 & 41.01 & 47.81 & 53.60 & 46.66 & 45.10 & 46.67 \\
\hline Kirov region & 20.00 & 20.62 & 25.18 & 33.36 & 42.68 & 49.44 & 45.99 & 44.51 & 46.92 \\
\hline $\begin{array}{l}\text { Nizhny } \\
\text { Novgorod } \\
\text { region }\end{array}$ & 22.60 & 22.01 & 25.37 & 30.31 & 36.62 & 41.11 & 36.14 & 34.26 & 36.00 \\
\hline $\begin{array}{l}\text { Orenburg } \\
\text { region }\end{array}$ & 22.51 & 22.69 & 27.23 & 34.26 & 43.44 & 54.31 & 48.11 & 46.94 & 47.18 \\
\hline Penza region & 17.15 & 17.34 & 20.91 & 27.98 & 35.35 & 42.12 & 37.17 & 38.27 & 39.16 \\
\hline $\begin{array}{c}\text { Samara } \\
\text { region }\end{array}$ & 30.63 & 28.90 & 33.90 & 40.59 & 43.55 & 41.34 & 37.29 & 36.36 & 37.32 \\
\hline $\begin{array}{c}\text { Saratov } \\
\text { region }\end{array}$ & 19.73 & 20.06 & 24.12 & 31.96 & 41.05 & 46.93 & 42.28 & 42.41 & 44.15 \\
\hline $\begin{array}{l}\text { Ulyanovsk } \\
\text { region }\end{array}$ & 22.84 & 26.99 & 33.80 & 44.12 & 55.17 & 58.93 & 47.16 & 45.33 & 47.19 \\
\hline
\end{tabular}

This indicator has decreased slightly from the average in the Russian Federation, but on average in the regions accounts payable is more than $40 \%$ of the average wage. The largest indicators were recorded in the Republic of Bashkortostan, Chuvashia, Perm region, Kirov, Orenburg, and Ulyanovsk regions. An important problem is the level of overdue debt. Another source of alternative information about the level of creditworthiness of citizens is the reports of the FSSP [17] (figure 8, 9).

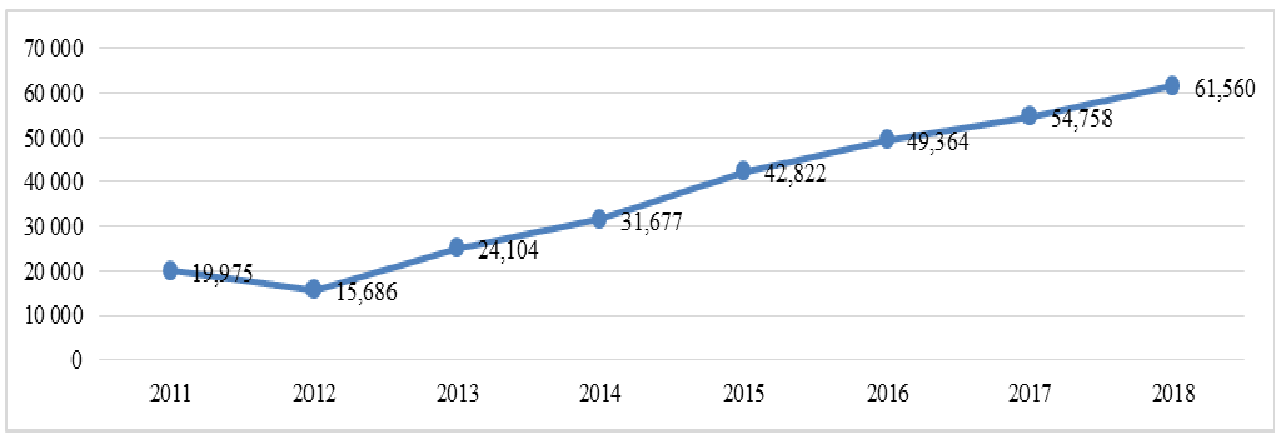

Fig. 8. Number of cases for debt collection from the Federal tax service in favor of credit organizations in the Kirovregion, units. 


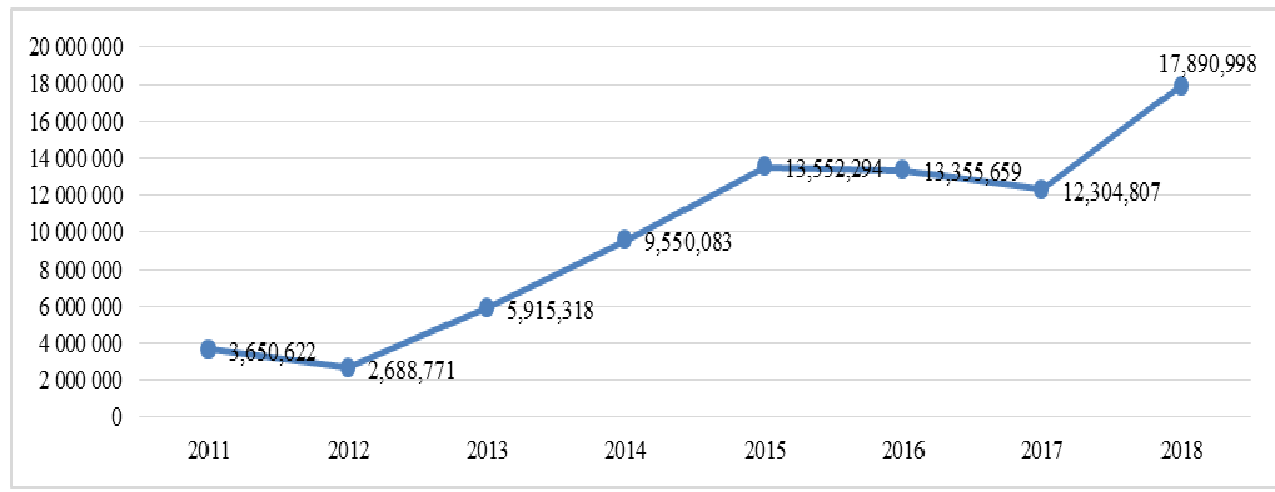

Fig 9. Amount of debt collection from the Federal tax service in favor of credit organizations in the Kirov region, RUB.

Thus, the number of cases for recovery increased by 3 times, and the amount of bribes more than 5 times.

The problem of credit statistics is compounded by the fact that there is no statistics on credit in microfinance and non-Bank credit organizations.

Only in Kirov there are:

11 non-Bank credit organizations

25 microfinance organizations.

This does not include online lending.

We can only guess how many people are credited in these organizations and online resources, under what collateral and how debts are collected there.

An important problem is the problem of collection agencies-this is the creation of additional social tension. This arises in connection with egregious ways of collecting debts:

1 Psychological pressure, intimidation;

2 Pressure on relatives, acquaintances, and neighbors;

3 Harassment at the place of work, study, or residence:

4 Attracting unscrupulous bailiffs;

5 Attracting unscrupulous clergy [10].

With the aggravation of the situation, an increasing number of experts are talking about total credit Amnesty, it should be noted that this Amnesty is already partially implemented by closing cases on loans according to paragraph 1 of part 1 of article 46 and paragraph 4 of part 1 of article 47 of the Federal law. Simply put, because the debtor has nothing to take [17] (figure 10.11).

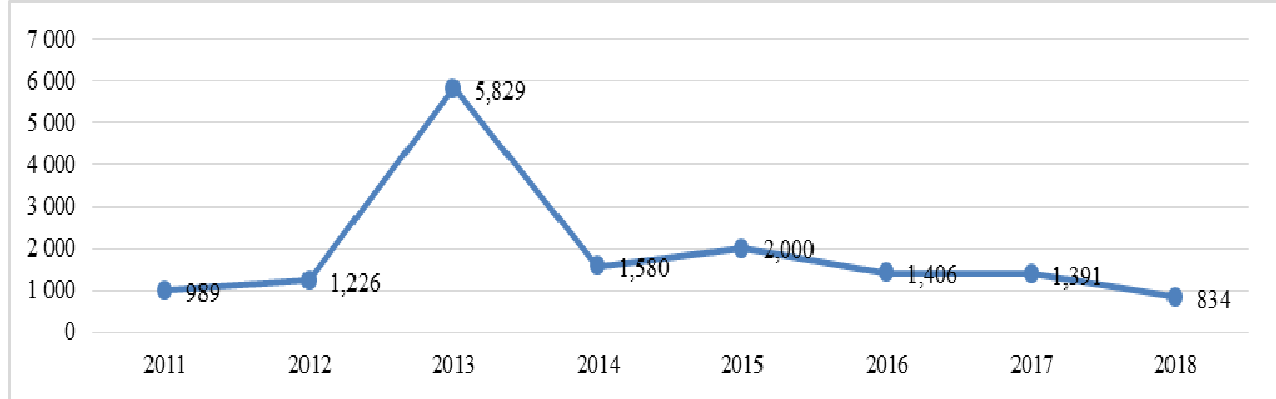

Fig 10. Closed cases due to lack of funds for repayment (p. 1 part 1 of article 46 and p. 4 part 1 of article 47 of the Federal law). 


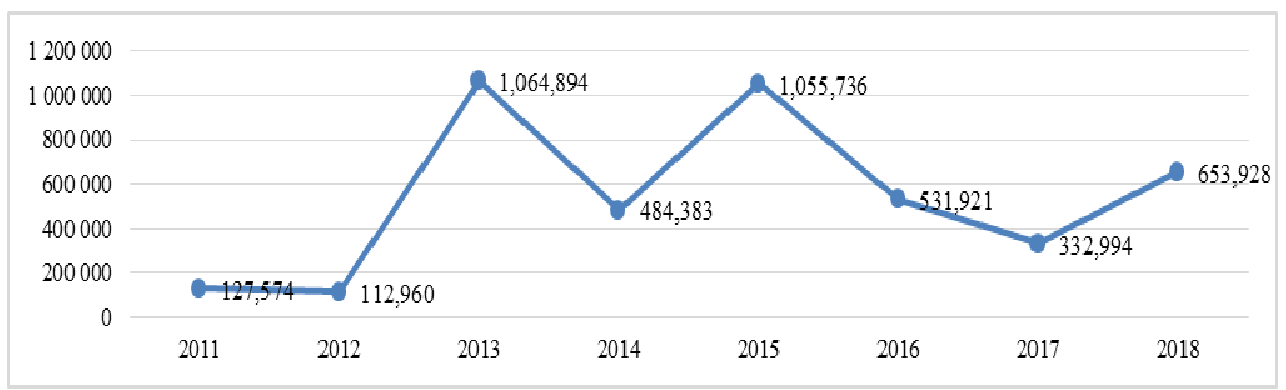

Fig 11. The amount of closing the debt due to lack of funds for repayment (p. 1 part 1 of article 46 and p. 4 part 1 of article 47 of the Federal law), thousand rubles.

Thus, the amount of closing cases increased by more than 5 times. The credit Amnesty has many and no less opponents, many political parties are speculating on this topic, but these measures, according to many economists, will have to be implemented.

\section{Conclusion}

Based on this research, the following conclusions can be drawn. In 2018, the portfolio of loans issued to the population increased by $22.4 \%$, which was a record increase since 2013 . For comparison, in 2017, 2016 and 2015, the increase was $+12.7 \%,+1.1 \%$ and $-5.7 \%$, respectively. In monetary terms, in Russia in 2018, banks issued loans and provided credit limits to the population in the amount of 12.5 trillion rubles against 9.2 trillion rubles in 2017, and the debt of the population to banks over the past year increased by 2.7 trillion rubles to 14.9 trillion rubles on January 1, 2019.

Against the background of the retail lending boom, the overdue debt of the population on Bank loans in nominal terms has significantly decreased - by 89 billion rubles to 760 billion rubles as of January 1, 2019. This led to the fact that in the past 2018, there was a sharp reduction in the share of overdue debt owed by the population to banks, from $7.0 \%$ on January 1, 2018 to $5.1 \%$ at the beginning of this year. Thus, the share of overdue debt decreased both due to the growth of the population's debts to banks, and due to a tangible improvement in the payment discipline of the population.

According to the results of the study, Russian regions are very different in terms of the share of overdue debt on Bank loans to the population. In five regions, the share of arrears exceeds $7.5 \%$, and in three regions, the share of overdue debt is less than $2.5 \%$. In General, the median value of the share of overdue loans to the population at the end of 2018 was $5.1 \%$. For comparison, in 2017, the median share of arrears in Russian regions was at the level of $7.0 \%$, and in $2016-7.9 \%$.

In terms of the dynamics of delay, the regions of Russia showed almost synchronous results. In General, the share of overdue debt in 14 regions of the PFD decreased in 2018, and only in two it increased.

Based on the study, the following initiatives are proposed to reduce the population's debt burden in the regions of the Volga Federal district and the Russian Federation as a whole:

- granting credit Amnesty for people who find themselves in a difficult life situation when they lose their job, breadwinner, health, etc.;

- rational credit issuance and improvement of the partial reservation process of banks;

- development of standard projects to reduce costs or increase revenues, which can be financed from regional budgets;

- development of the financial education volunteer movement;

- restriction or complete termination of the activities of microfinance and non-Bank 
credit organizations;

- involvement of regional authorities and local self-government, employers in the work to stabilize the financial situation of households, holding a Federal competition for the best regional, municipal and corporate financial education programs for residents and employees.

\section{References}

1. A. P. Reilly, The Quarterly Review of Economics and Finance in press (2019)

2. N. Rivers, B. Plumptre, Case Studies on Transport Policy 6(4), 651-662 (2018)

3. S. Kim, N. Varanasi, Economic Modelling 81, 411-421 (2019)

4. M. D. Delis, I. Hasan, Journal of Financial Economics in press (2019)

5. E. Karanina, S. Alekseev, D. Loginov, IOP Conference Series: Earth and Environmental Science (2019)

6. D. Loginov, E. Karanina, M.V. Palkina, Lecture Notes in Networks and Systems (2020)

7. E.V. Karanina, O.A. Ryazanova, A.N. Timin, L.P. Domracheva, E3S Web of Conferences (2019)

8. M.A. Selivanova,Yu.M. Ilinykh, Journal «Standard of living of the population of the regions of Russia», 54-60 (2018) DOI: 10.24411/1999-9836-2018-10039

9. The banking sector (2020) http://cbr.ru/statistics/?PrtId=pdko

10. Annual report of the Bank of Russia for 2018 (2020) https://cbr.ru/Collection/Collection/File/19699/ar_2018.pdf

11. Report on the development of the banking sector and banking supervision in 2018 (2020) https://cbr.ru/Content/Document/File/72560/bsr_2018.pdf

12. Official report of Sberbank of Russia (2020) https://www.sberbank.com/common/img/uploaded/redirected/com/gosa2019/docs/sber bank-annual_report_2018_rus.pdf

13. Official website of Sberbank of Russia (2020) https://www.sberbank.com/ru/investorrelations/reports-and-publications/ras

14. Overview: the banking sector in 2018 https://www.banki.ru/news/research/?id=10890092

15. Official website of the OECD (2019) https://www.oecd.org

16. The Federal service of state statistics of the Electron (2019) http://www.gks.ru

17. T. Gorokhova, L. Pushkareva, M. Sredin, M. Pushkarev, E3S Web of Conferences 135, 04069 (2019). https://doi.org/10.1051/e3sconf/201913504069 